\title{
Seasonality of macroalgal communities in a subtropical drainage basin in Paraná state, southern Brazil
}

\author{
Branco, CCZ. *, Krupek, RA. and Peres, CK. \\ Laboratório de Biologia Aquática, Departamento de Ciências Biológicas, \\ Universidade Estadual Paulista - UNESP, \\ Av. Dom Antônio, 2100, CEP 19806-900, Assis, SP, Brazil \\ *e-mail: czbranco@assis.unesp.br
}

Received November 7, 2006 - Accepted March 16, 2007 - Distributed November 30, 2008

(With 6 figures)

\begin{abstract}
Seasonal dynamics of macroalgal communities was analyzed monthly by samplings in three stream segments of the Pedras River Basin, mid-south region of Paraná State, southern Brazil, from April 2004 to March 2005. The seasonal fluctuations in macroalgal species richness and abundance were correlated with selected environmental variables. In general, the seasonal distribution patterns of these communities were distinct from those reported from other tropical and temperate regions, with higher macroalgal richness and abundance observed from late spring to late fall. Multiple linear regression analysis revealed that the stream variable most closely related with the temporal distribution pattern observed was temperature, which had a very similar seasonal pattern to the biological parameters. On the other hand, the floristic composition was quite diverse in the streams sampled. Among the 25 taxa identified, only two were common to the three streams whereas 15 were restricted to a single sampling site. These data indicate that, although temperature seems to be an effective relationship with global temporal pattern, particular characteristics of each stream can strongly influence the seasonal tendencies in local scale. The results of Detrended Correspondence Analysis (DCA) and Cluster Analysis corroborated this observation.
\end{abstract}

Keywords: drainage basin, stream macroalgae, Brazil, seasonality, subtropical.

\section{Sazonalidade das comunidades de macroalgas em uma bacia de drenagem subtropical no estado do Paraná, sul do Brasil}

\begin{abstract}
Resumo
A dinâmica sazonal das comunidades de macroalgas foi analisada mensalmente através de amostragens em três segmentos de riachos da Bacia do Rio das Pedras, região centro-sul do Estado do Paraná, Sul do Brasil, de abril de 2004 a março de 2005. As flutuações sazonais na riqueza e abundância de espécies de macroalgas foram correlacionadas com variáveis ambientais selecionadas. Em geral, os padrões de distribuição sazonal destas comunidades foram distintos daqueles reportados para outras regiões tropicais e temperadas, com maiores valores de riqueza e abundância observados no período compreendido entre o final da primavera e o final do outono. As análises de regressão linear múltipla revelaram que a variável do riacho mais fortemente relacionada com o padrão de distribuição temporal observado foi a temperatura, que teve um padrão sazonal muito similar àqueles observados para os parâmetros biológicos. Por outro lado, a composição florística foi bastante diversa nos riachos amostrados. Dentre os 25 táxons identificados, somente dois foram comuns aos três riachos, enquanto que 15 foram restritos a um único ponto de amostragem. Estes dados indicam que, embora a temperatura pareça ter tido uma relação efetiva com o padrão temporal global, características particulares de cada riacho podem influenciar fortemente as tendências sazonais em escala local. Os resultados da Análise de Correspondência Destendenciada (ADC) e da Análise de Grupamento corroboraram esta observação.
\end{abstract}

Palavras-chave: bacia de drenagem, Brasil, macroalgas lóticas, sazonalidade, subtropical.

\section{Introduction}

The seasonal fluctuation in macroalgal communities is a phenomenon, as a rule, influenced by environmental factors (Necchi-Júnior and Pascoaloto, 1993). In temperate regions, the variation in quantity and quality of radiation has often been associated with the seasonal

variation pattern of such algal communities (Holmes and Whitton, 1981; Sheath and Burkholder, 1985; Steinman and McIntire, 1986; 1987; Sheath and Hambrook, 1990). On the other hand, variables associated with rainfall, particularly current velocity and turbidity, are considered as 
the most important factors influencing temporal fluctuations on macroalgae in tropical regions (Necchi-Júnior et al., 1991; Necchi-Júnior and Pascoaloto, 1993).

Investigations involving temporal monitoring of lotic macroalgal communities and its relationship with environmental characteristics are relatively scarce in Brazil. In addition, the few studies of this nature concerning Brazilian streams were almost entirely carried out in tropical regions in São Paulo State (Necchi-Júnior et al., 1991; Necchi-Júnior and Pascoaloto, 1993; Branco and Necchi-Júnior, 1997). An important exception is a study realized in terra-firme streams from forest reserve areas in Amazon State (Pascoaloto, 1999). Considering that Brazil has a vast territory with a great variety of tropical and subtropical regions, more seasonal studies from other Brazilian areas might be important to bring new ecological information about the stream macroalgal communities.

The present study was carried out to fulfil such scarcity, considering that southern Brazil, including Paraná State, represents an important subtropical region where the climatic characteristics are peculiar and the ecological patterns of stream macroalgae are poorly known. Thus, the main purpose of the present study was to analyze the seasonal dynamics of macroalgal communities and its relationship with environmental characteristics in three streams of the Pedras River Basin, located in a subtropical region of Paraná State, southern Brazil. Considering the climatic combination of the study region, especially the rainfall and temperature regimes, we raised the following initial hypothesis to be tested: due to peculiar rainfall regime (rainfall well-distributed throughout the year with no clear distinction between dry and wet seasons), pattern of temperature variation (hot summer and mild to cold winter) and altitudinal profile (mean altitude over than $1,000 \mathrm{~m}$ ) found in the study region we expect that the seasonality of lotic macroalgal communities, in terms of temporal distribution pattern and relation with stream variables, to be well distinct from that previously reported for tropical and temperate regions of the world (Sheath, 1984; Sheath and Burkholder, 1985; Sheath and Hambrook, 1990; Necchi-Júnior et al., 1991; NecchiJúnior and Pascoaloto, 1993; Branco and Necchi-Júnior, 1997).

\section{Material and Methods}

\subsection{Study area}

The study was carried out in three streams (Table 1) belonging to the Pedras River Basin (25 $5^{\circ} 13^{\prime}-25^{\circ} 26^{\prime} \mathrm{S}$ and $51^{\circ} 13^{\prime}-51^{\circ} 28^{\prime} \mathrm{W}$ ), a subtropical drainage basin located in Paraná State, southeastern Brazil. The climate of the study area corresponds to a variation of the humid subtropical (Cfa - according to the Köppen classification) (Wons, 1982). The rainfall is well distributed throughout the year; with annual means around $1,960 \mathrm{~mm}$ and the annual mean temperature ranging from 16.0 to $17.5{ }^{\circ} \mathrm{C}$. In addition, the Pedras River Basin is located at altitudes above $1,000 \mathrm{~m}$.

\subsection{Sampling procedures and data analyses}

The fieldwork was conducted during the period April 2004 to March 2005 by means of monthly sampling. Each sampling site consisted of $10 \mathrm{~m}$ reaches permanently established which were thoroughly examined, by means of the cross-transect technique (Sheath and Burkholder, 1985), for the presence of macroalgae. In addition, abundance of each species was estimated in terms of percent cover as described by Sheath and Burkholder (1985). We adopted the concept of macroalgae as defined by Sheath and Cole (1992). The following stream variables were analyzed in each sampling: depth, water temperature, turbidity, specific conductance, $\mathrm{pH}$, dissolved oxygen and current velocity. All measurements, but turbidity, were made directly in the field. With exception of depth, all variables were taken with a Consort C535 water quality checker. Depth was measured in the midpoint of each transect (10 replicates by sampling date) with the help of a measuring tape. Water samples were transported to the laboratory and turbidity was measured using a Hach 2100P turbidimeter. Current velocity was measured using a 2030R General Oceanics mechanical flow meter, at ten equally spaced points along the stream segments, and averaged. We also annotated substratum type (according to particle size classes given by Gordon et al., 1992). Rainfall data were obtained from the Department of Agriculture of the municipality of Guarapuava (PR, Brazil).

Table 1. Description of sampling sites in the Pedras River basin. $\mathrm{D}=$ mean depth; $\mathrm{MV}=$ marginal vegetation; $\mathrm{L}=$ location in drainage basin; $\mathrm{S}$ = substrate; $\mathrm{SH}=$ shading; and $\mathrm{W}=$ mean width.

\begin{tabular}{|c|c|}
\hline Number, name and location & Description \\
\hline 1 Guabiroba Stream & $\begin{array}{l}\text { 2-order; L: lower portion; D: } 27.5 \mathrm{~cm} \text {; W: } 2.5 \mathrm{~m} \text {; S: predominantly boulders and } \\
\text { pebbles; MV: well preserved Araucaria Forest; SH: heavily shaded. }\end{array}$ \\
\hline Pedras River & $\begin{array}{l}\text { 4-order; L: median portion; D: } 40.5 \mathrm{~cm} \text {; W: } 6.0 \mathrm{~m} \text {; S: predominantly boulders, } \\
\text { presence of aquatic macrophytes; MV: well preserved Araucaria Forest; } \mathrm{SH} \text { : } \\
\text { partially shaded. }\end{array}$ \\
\hline Saltinho Stream & $\begin{array}{l}\text { 2-order; L: upper portion; D: } 25.5 \mathrm{~cm} \text {; W: } 1.5 \mathrm{~m} \text {; S: predominantly gravel; MV: } \\
\text { disturbed Araucaria Forest; SH: partially shaded. }\end{array}$ \\
\hline
\end{tabular}


The Pearson product-moment correlation coefficient was applied to examine possible associations among physical, chemical and biological variables, whereas multiple linear regression analysis was applied in order to evaluate the combined effect of the most closely related variables (Sokal and Rohlf, 1981). In order to avoid adverse effects of multicollinearity in regression analysis, the independent variables were selected for each stream based on the correlations among them. Differences in means for stream variables and biological data among the sampling sites were tested by one-way analysis of variance (ANOVA, Sokal and Rohlf, 1981). Detrended Correspondence Analysis (DCA) and Cluster Analysis were applied to observe possible associations among sampling sites and dates based on composition of macroalgal communities. The analyses were performed with the statistical packages Statsoft Statistica, version 6.0, Minitab, version 10.1 (Ryan et al., 1985), Pcord, version 4.0 (McCune and Mefford, 1999) and Nt-Sys, version 2.1 (Romesburg, 1984; Rohlf, 2000).

\section{Results}

\subsection{Seasonal variation of the stream variables}

Maximum, minimum and mean values of the measured environmental variables revealed, in general, narrow temporal variation in the physical and chemical characterization among the three streams (Table 2, Figure 1). Seasonal fluctuation in precipitation showed an evenly rainfall pattern, with the high values in March and October 2004 and low in August 2004 (Figure 2). ANOVA showed significant differences among streams only for $\mathrm{pH}(\mathrm{F}=7.18$, $\mathrm{p}<0.01)$ and depth $(\mathrm{F}=3.76, \mathrm{p}<0.05)$.

\subsection{Seasonal dynamics of the stream macroalgal communities}

Site 1: 18 macroalgal species were identified at this sampling site, which was the highest number among the streams studied (Table 3). Species number per sampling date varied from 2 to $6(\overline{\mathrm{x}}=4.0 \pm 1.6)$ (Figure 3$)$. Generally, low values of abundance (percent cover between $0.5-15 \%, \bar{x}=5 \pm 4.5$ ) were observed, with maximum values in January and February (Figure 3).

$55 \%$ (10 taxa) of the macroalgae identified were observed exclusively in this stream (Table 3). Batrachospermum virgato-decaisneanum (Rhodophyta) and Tolypothrix byssoidea (Cyanophyta) were the species with higher number of occurrence, being observed in nine samplings ( $75 \%$ of all samplings). B. virgato-decaisneanum had the highest biomass in summer (Figure 4a), while T. byssoidea did not show any clear pattern of abundance variation throughout the study period, with very low values of percent cover in all sampling dates (Figure 4b). Species richness and abundance were positively correlated with water temperature $(r=0.639-0.832, \mathrm{p}<0.005)$ and negatively with current velocity $(\mathrm{r}=-0.583-0.684, \mathrm{p}<0.05)$. According to multiple regression analysis, temperature, $\mathrm{pH}$, specific conductance, turbidity, current velocity and rainfall accounted for $85.5 \%(\mathrm{~F}=4.89, \mathrm{p}=0.05)$ of the seasonal variation of the species number $(\mathrm{p}<0.05)$; however, only temperature showed significant correlation $(\mathrm{t}=3.46, \mathrm{p}<0.01)$.

Site 2: 10 macroalgal species were identified at this sampling site (Table 3 ). The species number per sampling date ranged from 0 to $3(\overline{\mathrm{x}}=1.5 \pm 1.0)$ (Figure 3 ). Abundance of stream macroalgal communities showed narrow variation, with low values $(0-18 \%, \bar{x}=2.3 \pm 5.0)$ along the study period, except for an unexpected high value observed in February (Figure 3).

$40 \%$ of the macroalgal species (4 taxa) were found exclusively at this sampling site (Table 3). Pleurocapsa fluviatilis (Cyanophyta) was the species occurring during the longest period (four samplings, 33\% of all sampling dates) (Figure 4c). Although P. fluviatilis has often occurred at very low abundances, its highest cover was

Table 2. Environmental variable values measured for each sampling site at the Pedras River Basin from April/04 to March/05.

\begin{tabular}{lccc}
\hline \multicolumn{1}{c}{ Variable } & Site 1 & Site 2 & Site 3 \\
\hline Temperature $\left({ }^{\circ} \mathrm{C}\right)$ & $13.4-20.1$ & $12.7-24.6$ & $14.0-25.2$ \\
& $(\overline{\mathrm{x}}=16.7 \pm 2.6)$ & $(\overline{\mathrm{x}}=18.6 \pm 4.1)$ & $(\overline{\mathrm{x}}=18.6 \pm 4.1)$ \\
Specific conductance & $46.1-410.0$ & $29.9-741.0$ & $25.6-829.0$ \\
$\left(\mu \mathrm{S} . \mathrm{cm}^{-1}\right)$ & $(\overline{\mathrm{x}}=233.9 \pm 130.5)$ & $(\overline{\mathrm{x}}=220.1 \pm 218.5)$ & $(\overline{\mathrm{x}}=240.7 \pm 225.6)$ \\
Dissolved oxygen & $57-91$ & $56-90$ & $51-86$ \\
$(\%$ saturation $)$ & $(\overline{\mathrm{x}}=73.6 \pm 9.7)$ & $(\overline{\mathrm{x}}=69.8 \pm 10.3)$ & $(\overline{\mathrm{x}}=64.4 \pm 9.7)$ \\
$\mathrm{pH}$ & $7.11-8.24$ & $7.12-7.79$ & $6.42-7.77$ \\
& $(\overline{\mathrm{x}}=7.5 \pm 0.28)$ & $(\overline{\mathrm{x}}=7.4 \pm 0.24)$ & $(\overline{\mathrm{x}}=7.0 \pm 0.45)$ \\
Turbidity & $1.3-11.5$ & $2.1-35.4$ & $1.6-8.7$ \\
$(\mathrm{NTU})$ & $(\overline{\mathrm{x}}=5.9 \pm 4.18)$ & $(\overline{\mathrm{x}}=10.5 \pm 10.2)$ & $(\overline{\mathrm{x}}=5.1 \pm 2.6)$ \\
Depth & $13.9-58.7$ & $19.3-147.0$ & $8.9-52.7$ \\
$(\mathrm{~cm})$ & $(\overline{\mathrm{x}}=24.8 \pm 12.9)$ & $(\overline{\mathrm{x}}=45.6 \pm 33.9)$ & $(\overline{\mathrm{x}}=23.0 \pm 13.6)$ \\
Current Velocity & $22.4-87.8$ & $23.3-187.5$ & $23.2-144.6$ \\
$(\mathrm{~cm} / \mathrm{s})$ & $(\overline{\mathrm{x}}=43.0 \pm 19.1)$ & $(\overline{\mathrm{x}}=51.5 \pm 43.7)$ & $(\overline{\mathrm{x}}=66.9 \pm 36.9)$ \\
\hline
\end{tabular}



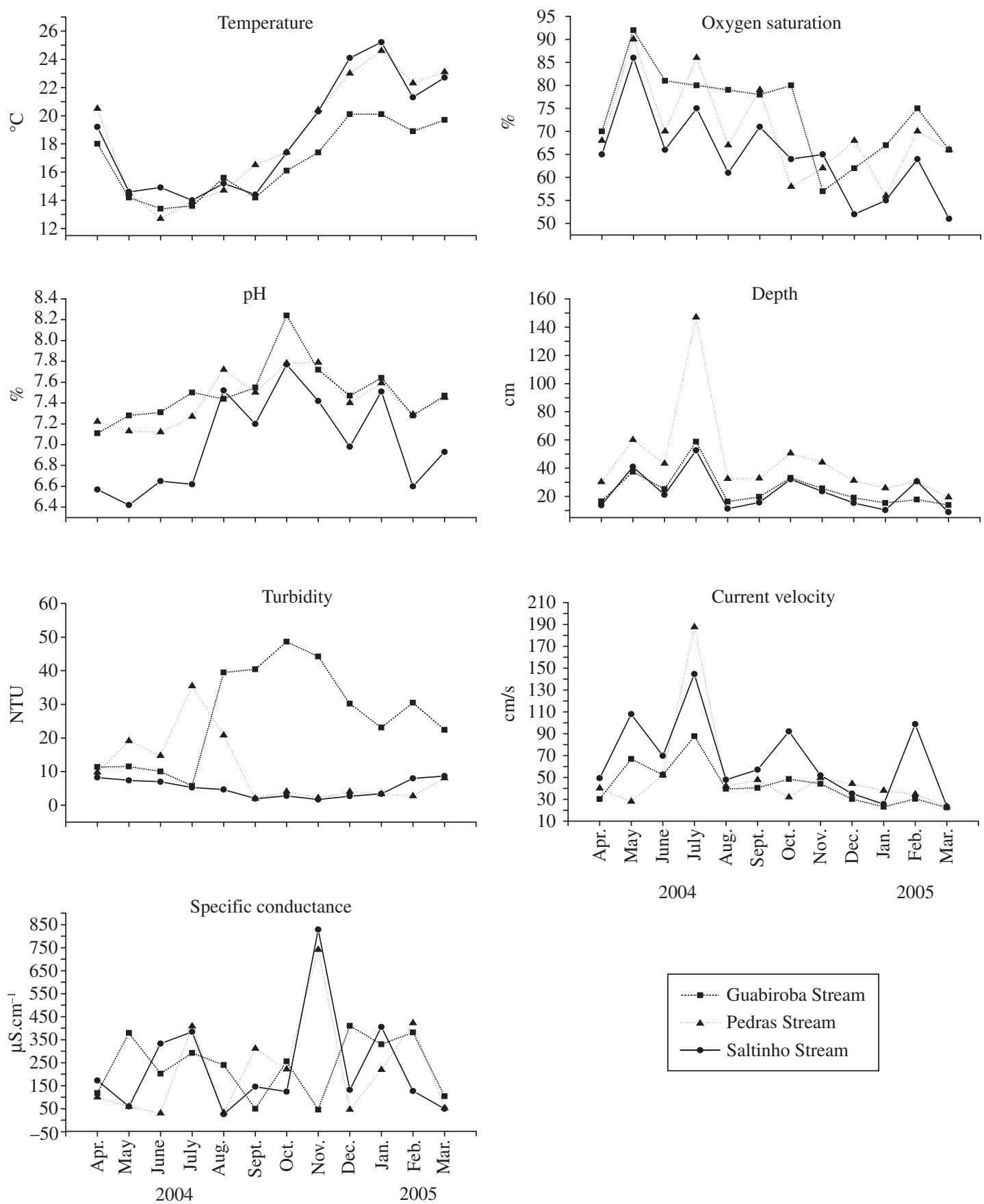

Figure 1. Variation of temperature, oxygen saturation, $\mathrm{pH}$, depth, turbidity, current velocity and specific conductance in Guabiroba Stream, Pedras River and Saltinho Stream from April/04 to May/05.

observed in fall. On the other hand, B. puiggarianum occurred on three sampling dates, but had higher abundance in winter (Figure 4d). Species richness was negatively correlated with depth $(\mathrm{r}=-0.568, \mathrm{p}<0.05)$. Multiple regression analysis showed neither an overall interrelationship among variables, nor the influence of any independent variable, to explain species richness $(\mathrm{F}=1.21$, $\mathrm{p}=0.42)$ and abundance $(\mathrm{F}=0.63, \mathrm{p}=0.70)$ variation.
Site 3: The macroalgal community had the lowest species number at this stream, (eight identified taxa, Table 3). The species number per sampling date ranged from 0 to $5(\overline{\mathrm{x}}=2.8 \pm 1.4)$. Abundance of this macroalgal community was the lowest among the investigated streams $(0-6 \%, \overline{\mathrm{x}}=1.55 \pm 1.9)$ with most sampling values with cover lower than $1 \%$ (Figure 3). 


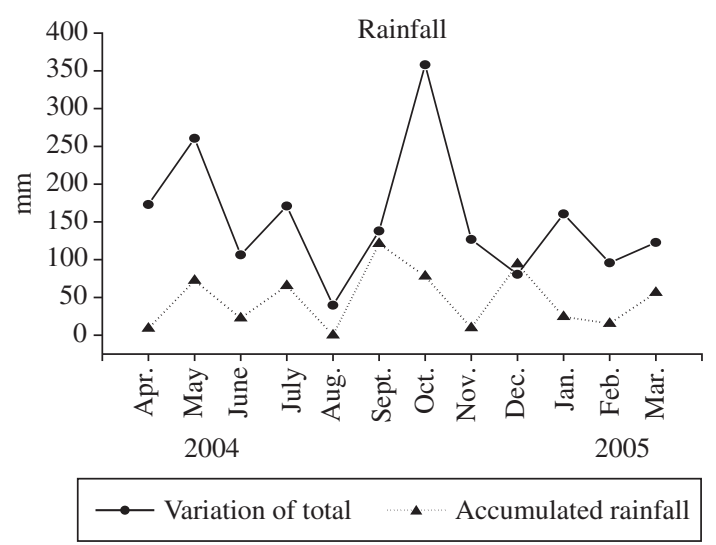

Figure 2. Variation of total and accumulated rainfall seven days before the sampling in Pedras River Basin from April/04 to May/05.
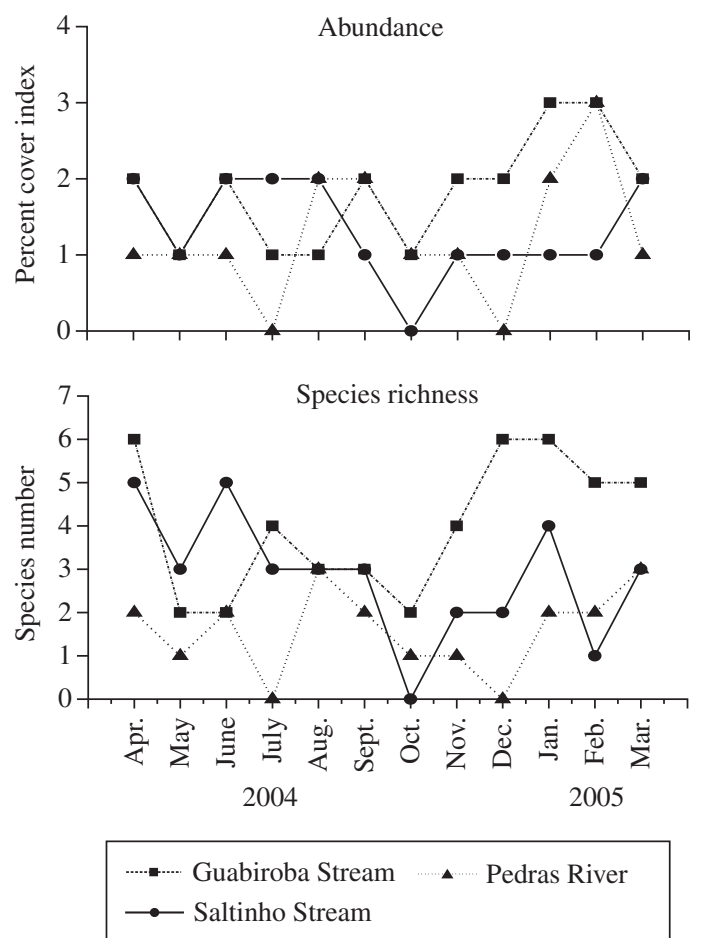

Figure 3. Variation of species number (species richness) and abundance (percent cover index) in Guabiroba Stream, Pedras River and Saltinho Stream from April/04 to May/05. The values corresponding to the percent cover index are: $0=$ absent $1=<1 \% ; 2=1-10 \% ; 3=11-25 \% ; 4=26-50 \%$; $5=51-75 \% ; 6=76-100 \%$.

Two species were exclusively found at this sampling site (Table 3). Batrachospermum puiggarianum (Rhodophyta) was observed in eight of the 12 samplings (67\%), while Phormidium retzii (Cyanophyta) occurred on six sampling dates throughout the study. B. puiggarianum had the highest cover in April/04,
June/04 and July/04, and very low values in other samplings (Figure 4e). P. retzii showed no clear seasonal pattern (Figure 4f). Species richness and abundance were not correlated to any stream variables. Multiple regression analysis showed neither an overall interrelationship among variables, nor the influence of any independent variable, to explain species richness $(\mathrm{F}=1.25, \mathrm{p}=0.41)$ and abundance $(\mathrm{F}=3.45, \mathrm{p}=0.09)$ variation.

\subsection{Global analyses}

The seasonal variation patterns in species richness and abundance were relatively similar in the streams analyzed. Generally, species richness (Figure 3) was higher from late spring (November) to early fall (April), followed by a relative wide oscillation until early spring, when the lowest values were found (except for Pedras River, with fluctuations extending until December/05). The seasonal fluctuation of abundance (Figure 3) was similar to that observed for species richness (with positive correlation in all sampling sites, $r=0.570-0.730$, $\mathrm{p}<0.05)$.

DCA (Figure 5) revealed that, both sampling dates and species were mostly positioned at the right side of Axes 1 and 2, without any clear pattern of distribution. However, the explicability associated to Axes 1 (20.4\%) and $2(20.1 \%)$ were relatively low. Cluster Analysis (Figure 6), similarly to that observed in DCA, showed no consistent groupings for sampling dates and species. In this case, however, the cophenetic correlation revealed a high value $(r=0.805)$. As a rule, the distribution of sampling dates of the streams reflected the strong occurrence of species with occasional presence. In Site 1, only four species (22.2\% of the species, Table 3 ) were registered in at least four sampling dates. Similarly, in Site 2, out of the ten species identified, only a single one was recorded in four or more samplings. In site 3, five of the eight species were collected in four or more sampling dates (Table 3). This characteristic resulted in a relatively more homogenous grouping of the sampling dates for this stream (Figures 5 and 6).

\section{Discussion}

The seasonal patterns of macroalgal species richness and abundance found in the Pedras River Basin were quite different from those reported for lotic ecosystems of other temperate (Sheath, 1984; Sheath and Burkholder, 1985; Sheath and Hambrook, 1990) and tropical (NecchiJúnior et al., 1991; Necchi-Júnior, 1992; 1993; NecchiJúnior and Pascoaloto, 1993; Branco and Necchi-Júnior, 1997) regions. Pedras River Basin showed highest species richness and abundance of the macroalgal communities occurring from late spring to early fall, while in temperate and tropical regions this period corresponds to late fall to early spring.

Multiple regression analysis, despite weak correlations observed, suggested that, among the environmental variables analyzed, temperature is the one that most in- 
Table 3. Occurrence of macroalgal species during the period April/04 to March/05 in the Pedras River Basin ( $\mathrm{n}=12)$.

\begin{tabular}{|c|c|c|c|}
\hline Taxa & $\begin{array}{c}\text { Site } 1 \\
\text { (Guabiroba } \\
\text { Stream) }\end{array}$ & $\begin{array}{c}\text { Site } 2 \\
\text { (Pedras River) }\end{array}$ & $\begin{array}{c}\text { Site } 3 \\
\text { (Saltinho } \\
\text { Stream) }\end{array}$ \\
\hline \multicolumn{4}{|l|}{ CYANOPHYTA } \\
\hline $\begin{array}{l}\text { Nostochopsis lobatus } \\
\text { Wood ex Bornet and Flahaut [Nlb] }\end{array}$ & Apr. & - & - \\
\hline $\begin{array}{l}\text { Phormidium puteale } \\
\text { (Montagne ex Gomont) } \\
\text { Anagnostidis and Komárek [Ppt] }\end{array}$ & July, Oct. & - & - \\
\hline $\begin{array}{l}\text { P. retzii } \\
\text { Gomont }[\mathrm{Prt}]\end{array}$ & $\begin{array}{l}\text { Apr., Sept., } \\
\text { Nov., Jan., Feb. }\end{array}$ & Apr. & $\begin{array}{l}\text { Apr., May, Aug., } \\
\text { Sept., Nov., Jan. }\end{array}$ \\
\hline $\begin{array}{l}\text { Geitlerinema amphibium } \\
\text { (C. Agardh ex Gomont) Anagnostidis [Gam] }\end{array}$ & Aug. & - & - \\
\hline Phormidium sp. [Pho] & Feb. & - & - \\
\hline $\begin{array}{l}\text { Pleurocapsa fluviatilis } \\
\text { Langherheim [Pfl] }\end{array}$ & - & $\begin{array}{l}\text { Apr., May., Jan., } \\
\text { Mar. }\end{array}$ & - \\
\hline $\begin{array}{l}\text { Tolypothrix byssoidea } \\
\text { (Hassal) Kirchner [Tbs] }\end{array}$ & $\begin{array}{l}\text { Apr., May, June, } \\
\text { July, Sep., Nov., } \\
\text { Dec., Jan., Mar. }\end{array}$ & Jun., Nov. & June, July \\
\hline CHLOROPHYTA & - & - & - \\
\hline Chaetophora elegans (Roth) C. Agardh [Cel] & Jan. & - & \\
\hline $\begin{array}{l}\text { Draparnaldia mutabilis } \\
\text { (Roth) Bory [Dmt] }\end{array}$ & Apr., Dec., Mar. & - & $\begin{array}{l}\text { Apr., June, } \\
\text { Aug., Jan. }\end{array}$ \\
\hline $\begin{array}{l}\text { Ecballocystis pulvinata } \\
\text { Bohlin [Epl] }\end{array}$ & - & - & $\begin{array}{l}\text { Apr., Dec., Jan., } \\
\text { Feb., Mar. }\end{array}$ \\
\hline Microspora stagnorum (Kützing) Lagerheim [Mst] & Dec., Mar. & - & - \\
\hline M. quadrata Hazen [Mqd] & - & Aug. & - \\
\hline Oedogonium sp. [Oed] & - & Feb. & - \\
\hline Palmella mucosa Kützing [Pmc] & Dec. & - & - \\
\hline Spirogyra sp. [Spi] & Feb. & Jan., Feb. & - \\
\hline $\begin{array}{l}\text { Stigeoclonium amoenum } \\
\text { Kützing [Sam] }\end{array}$ & $\begin{array}{l}\text { July, Aug., Nov., } \\
\text { Feb. }\end{array}$ & - & - \\
\hline Tetraspora lubrica (Roth) C. Agardh [Tlb] & Dec. & Sept. & - \\
\hline T. gelatinosa (Vaucher) Desvaux [Tgl] & Dec., Jan., Mar. & Aug., Mar. & - \\
\hline Zygnema sp. [Zyg] & - & Mar. & - \\
\hline HETEROKONTOPHYTA & - & - & - \\
\hline Vaucheria sp. [Vau] & Apr. & - & - \\
\hline \multicolumn{4}{|l|}{ RHODOPHYTA } \\
\hline $\begin{array}{l}\text { Batrachospermum flageliforme } \\
\text { (Sirodot) Necchi [Bfl] }\end{array}$ & June, July, Mar. & - & - \\
\hline $\begin{array}{l}\text { B. puiggarianum } \\
\text { Grunow in Wittrock \& Nordstedt [Bpg] }\end{array}$ & - & Aug., Sept., Oct. & $\begin{array}{l}\text { Apr., May, June, } \\
\text { July, Aug., Sept, } \\
\text { Nov., Jan. }\end{array}$ \\
\hline $\begin{array}{l}\text { B. virgato-decaisneanum } \\
\text { Sirodot }[\mathrm{Bvd}]\end{array}$ & $\begin{array}{c}\text { Apr., May, Aug., } \\
\text { Sept., Oct., } \\
\text { Nov., Jan., } \\
\text { Feb., Mar. }\end{array}$ & - & $\begin{array}{l}\text { Aug., May, } \\
\text { June, July, } \\
\text { Mar. }\end{array}$ \\
\hline B. virgatum (Kutzing) Sirodot [Bvr] & Jan. & - & Mar. \\
\hline Batrachospermum sp. [Bat] & - & - & May, Sept., Dec. \\
\hline
\end{tabular}



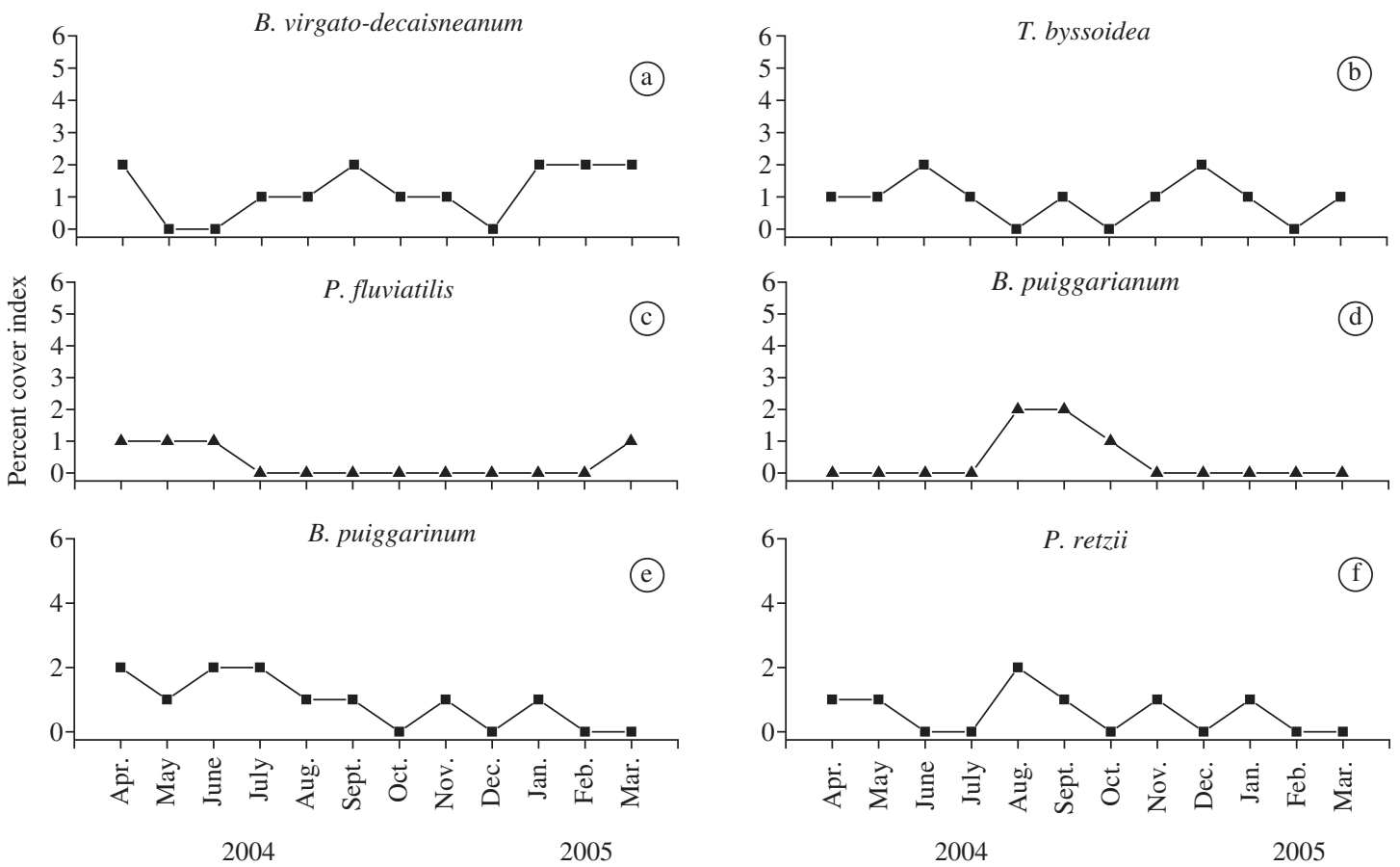

Figure 4. Variation in percent cover of a) Batrachospermum virgato-decaisneanum and b) Tolypothrix bissoidea in Guabiroba Stream; c) Batrachospermum puiggarianum and d) Pleurocapsa fluviatilis in Pedras River; e) Batrachospermum puiggarianum and f) Phormidium retzii in Saltinho Stream. The values corresponding to the percent cover index are: $0=$ absent $1=<1 \% ; 2=1-10 \% ; 3=11-25 \% ; 4=26-50 \% ; 5=51-75 \% ; 6=76-100 \%$.

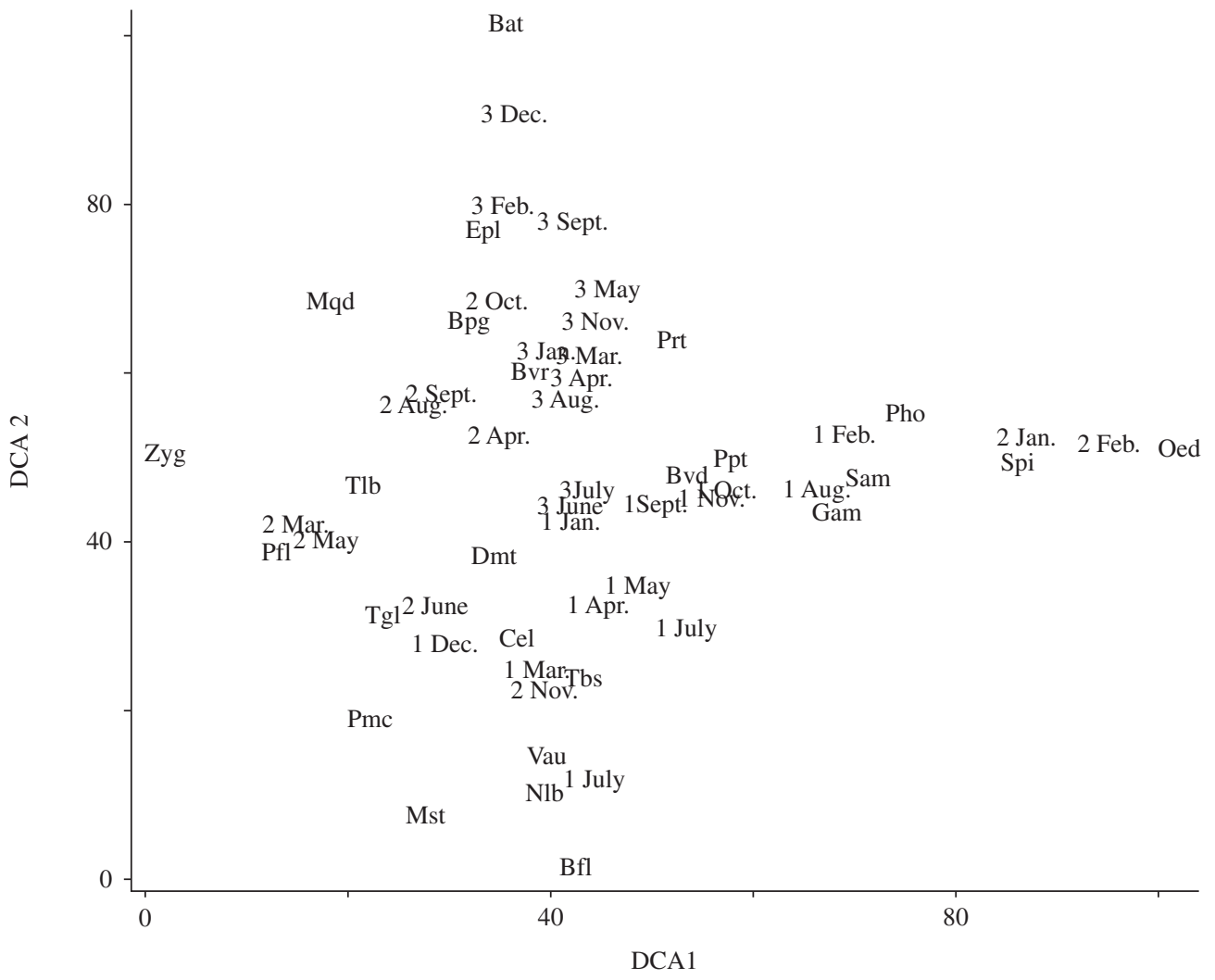

Figure 5. DCA analysis of the sampling dates of the sampling sites during the study period based on species composition. Sampling dates and species abbreviations are in accordance with Table 3. 


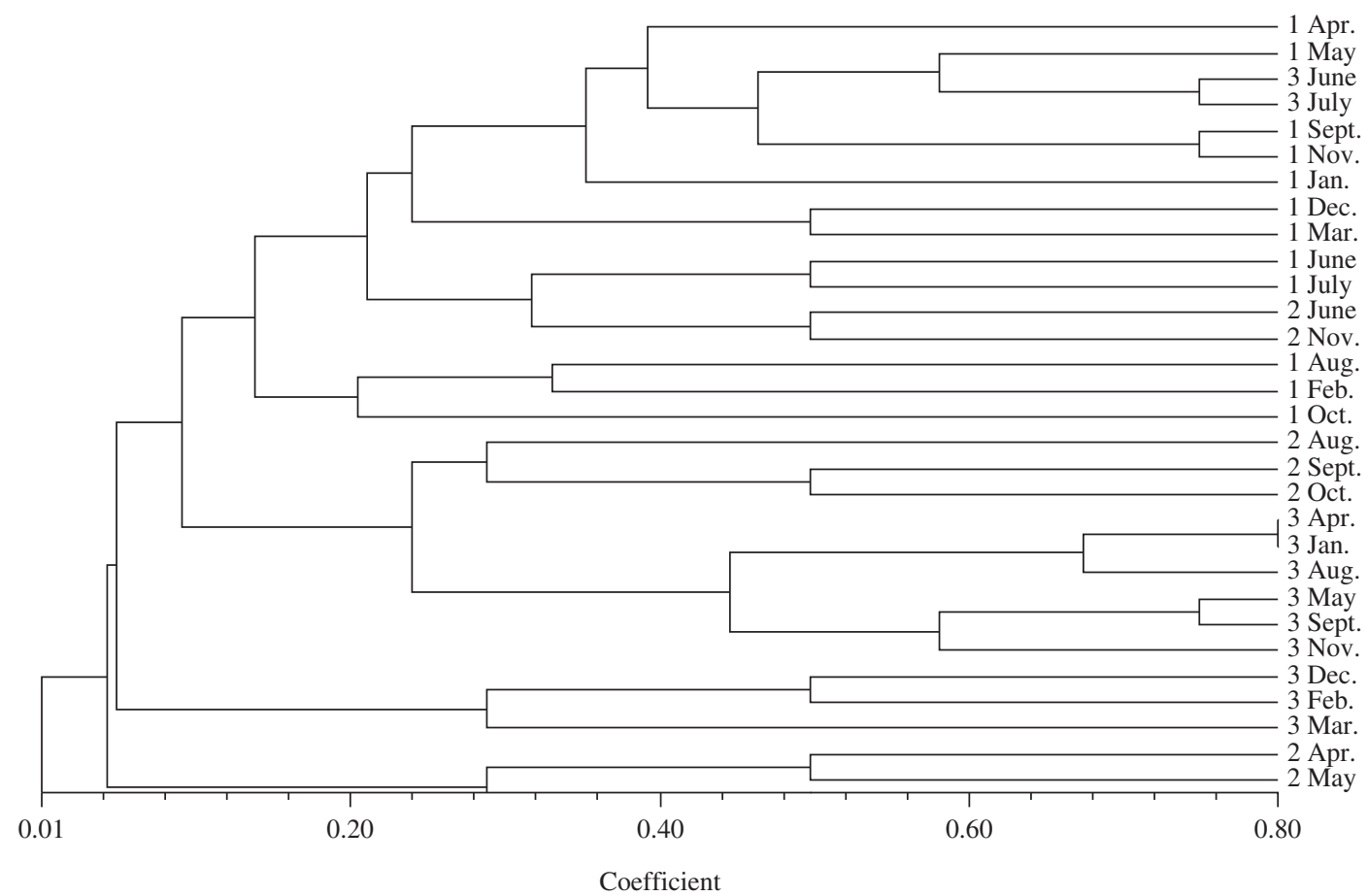

Figure 6. Cluster analysis of the sampling dates in the Pedras River Basin from April 2004 to March 2005 according to the macroalgal occurrence. Sampling dates abbreviations are in accordance with Table 3.

fluenced the seasonal variation of the macroalgal communities. In addition, the seasonal fluctuation of the temperature was closely associated to that observed in species richness and abundance, with highest values during the period of late spring to early fall. Thus, considering the initial hypothesis, the results suggested that the pattern of variation of temperature had an effective influence on temporal fluctuation of the macroalgal communities investigated. In contrast, a similar influence was not observed for rainfall regime and altitudinal profile. Thus, the hypothesis was partly confirmed.

On the other hand, DCA and Cluster Analysis indicated a strong occurrence of species with occasional presence. These results indicated that, although temperature could be effectively related to the global seasonal patterns, the particular characteristics of each sampling site, at every time, seemed to be important to determine the local temporal tendencies. Thus, the present study suggested that global characteristics, especially temperature, must be considered in the seasonal fluctuation of the macroalgal communities in subtropical regions of southern Brazil (the influence of temperature under seasonal fluctuations of stream macroalgal communities has been frequently reported for temperate and tropical regions, Sheath and Burkholder, 1985, Sheath and Hambrook, 1990, Necchi and Pascoaloto, 1993) but, otherwise, the local features of each stream segment should also be considered. Similar observations were previously reported by Branco and Necchi-Júnior (1997) in a study carried out in a Brazilian tropical region.
Acknowledgements - We are grateful to the Department of Environment and Forest Development of the municipality of Guarapuava (PR, Brazil) and to UNICENTRO (PR, Brazil), particularly Dr. Maurício Camargo, for logistic assistance in fieldwork, and to $\mathrm{CNPq}$ for research grants to RAK (130196/04-5) and CCZB (520257/01-4).

\section{References}

BRANCO, LHZ. and NECCHI-JÚNIOR, O., 1997. Seasonality of macroalgae in three Tropical drainage basins in São Paulo State, southeastern Brazil. Arch. Hydrobiol., vol. 141, no. 1, p. 75-91.

GORDON, ND., McMAHON, TA. and FINLAYSON, BL., 1992. Stream hydrology, an introduction for ecologists. Chichester: John Wiley and Sons.

HOLMES, NTH. and WHITTON, BA., 1981. Phytobenthos of River Tees and its tributairies. Freshw. Biol., vol. 11, no. 2, p. 139-163.

McCUNE, B. and MEFFORD, MJ., 1999. Multivariate Analysis of Ecological Data. Glendem Beach: MjM Software.

NECCHI-JÚNIOR, O., 1992, Macroalgae dynamics in a spring in São Paulo State, southeastern Brazil. Arch. Hydrobiol., vol. 124 , no. 4 , p. 489-499.

-, 1993. Distribution and seasonal dynamics of Rhodophyta in the Preto River basin, southeastern Brazil. Hydrobiologia, vol. 250 , no. 2, p. 81-90.

NECCHI-JÚNIOR, O., DIP, MR. and GÓES, RM., 1991. Macroalgae of a stream in southeastern Brazil: composition, 
seasonal variation and relation to physical and chemical variables. Hydrobiologia, vol. 213, no. 3, p. 241-250.

NECCHI-JÚNIOR, O. and PASCOALOTO, D., 1993. Seasonal dynamics of macroalgal communities in the Preto River basin, São Paulo, southeastern Brazil. Arch. Hydrobiol., vol. 129, no. 2, p. 231-252.

ROHLF, FJ., 2000. NTSYS-pc: numerical taxonomy and multivariate analysis system. New York: Exeter Software.

ROMESBURG, HC., 1984. Cluster Analysis for Researches. Belmont: Lifetime Learning Publications.

RYAN, BF., JOINER, BL. and RYAN, TA., 1985. Minitab handbook. Boston: Duxbury Press.

SHEATH, RG., 1984. The biology of freshwater red algae. In ROUND, FE. and CHAPMAN, DJ. (Eds.). Progress in phycological research, 3. Bristol: Biopress Ltda.

SHEATH, RG. and BURKHOLDER, J., 1985. Characteristics of softwater stream in Rhode Island. II: Composition and seasonal dynamics of macroalgae communities. Hydrobiologia, vol. 128 , no. 2 , p. 109-118.
SHEATH, RG. and COLE, KM., 1992. Biogeography of stream macroalgae in North America. J. Phycol., vol. 28, no. 4, p. $448-460$

SHEATH, RG. and HAMBROOK, JA., 1990. Freshwater ecology. In COLE, KM. and SHEATH, RG. (Eds.). Biology of red algae. Cambridge: Cambridge University Press.

SOKAL, RR. and ROHLF, FJ., 1981. Biometry. New York: W. H. Freeman.

STEINMAN, AD. and McINTIRE, CD., 1986. Effects of current velocity and light energy on the structure of periphyton assemblages in laboratory streams. J. Phycol., vol. 22, no. 3, p. $352-361$.

-, 1987. Effects of irradiance on the community structure and biomass of algal assemblages in laboratory streams. Can. J. Fish. Aquat. Sci., vol. 44, p. 1640-1648.

WONS, I., 1982. Geografia do Paraná. Curitiba: Editora Ensino Renovado. 